\title{
MARKETING DIALOGUE WITH PRESSURE GROUPS
}

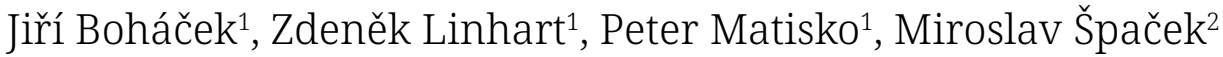 \\ ${ }^{1}$ Department of Marketing, University of Economics and Management, Nárožní 2600/9A, 15800 Praha 5, Czech \\ Republic \\ 2 Department of Management, University of Economics and Management, Nárožní 2600/9A, 15800 Praha 5, \\ Czech Republic
}

Link to this article: https://doi.org/10.11118/actaun.2021.018

Received: 15. 4. 2020, Accepted: 26. 2. 2021

To cite this article: BOHÁČEK JIŘÍ, LINHART ZDENĚK, MATISKO PETER, ŠPAČEK MIROSLAV. 2021. Marketing Dialogue With Pressure Groups. Acta Universitatis Agriculturae et Silviculturae Mendelianae Brunensis, 69(2): 211220.

\begin{abstract}
CSR actions are often controversial due to either the excessive voluntary or narrow standardized approach. The objective of this article is to find indices, which homogenize CSR campaigns of corporations according to specific attitudes and behaviour of individuals. Cluster analysis has significantly differentiated CSR volunteering contributors from non-volunteering critics. A small cluster of non-volunteering respondents calls for support of kids, criminals and addicts. Volunteering clusters are composed of employed respondents who are predominantly calling for equality and environment according to their work and leisure interest. The technology volunteering from the previous year disappeared from the list of CSR of respondents as it was aggregated either to other priority or finished and forgotten due to interests in a new project. Results demonstrate that responsibility is not related only to people in need but calls for simplification of complex public, corporate and human relationships to focus on its development.
\end{abstract}

Keywords: volunteering and non-volunteering contributors, CSR campaigns homogenization indices, social equality

\section{INTRODUCTION}

Pressure groups may represent a powerful minority force in society and exert political influence on the detriment of the majority of society. Marketing always promotes efficiently the most specific differentiating factor, which may lead both to cohesion or split of partners. Therefore, we want to sort a list of factors, which are increasing efficiency, best practices, and actions to adapt such global standards as ISO 26000:2010 to all types of organizations regardless of their activity, size or location rather than requirements. Certification of CSR is proving to the most of respondents that the organisation is ethical and contributes to sustainable development. But certification of CSR for a powerful minority of respondents makes sense if wealth increases and negatives of migration are prevented.
An example of a company taking responsible action to decrease the burden of migration is pledge of Starbucks to hire 10.000 refugees in the following five years, which has received mixed attention (Hersher, 2017). United Nations Sustainable Development Goals (UNSDG) like "End poverty in all its forms everywhere" are also aiming to stop reasons of migration. This delegation of migration control functions to private actors is largely unregulated and the multi-layered policy implications are not well understood (Bloom, 2015). Rosling et al. (2018) are showing evidence and techniques used to convince about $70 \%$ of people and $85 \%$ of academics who are denying that poverty was eradicated 30 years ago. These lasting denials show that control of triggers, which release migration processes were not found and are not part of priorities of corporate social responsibility (CSR). We will search the relationship between 
the general pattern of investments incentives, which states pay to entering or leaving global companies and remittances families pay to retain migrated kids in wealthy countries. Our hypothesis is that global business entering the country with or without investment subsidies increases outmigration of young educated people. Having kids settled in prosperous countries is perceived as big social innovation by families in low developed countries. Oeij et al. (2019) wanted to know more about the combinations of variables that drive social innovation to scale up.

The objective of this article was to find indices, which homogenize CSR campaigns of attitudes towards types of CSR messages (Ast) oppose to general attitude (Ag) towards CSR were quantified by questionnaire on CSR targets of few big companies over several years: Škoda Auto, Accenture, Sknaska, Pilsner Urquel, KPMG, and ČEZ.

\section{MATERIALS AND METHODS}

Efficiency of CSR was derived from the relationship between employer branding, reconstruction of administrative structures, advertising, and CSR of companies to sustain its image and loyalty.

\section{Outer CSR and Inner Employer Branding Relationship}

Employer branding represents a company's brand promise to the people who work there, the people who want to work there, and the people the company wants to attract. CSR activities of people who work there often target people who want to work there, and the people the company wants to attract. Employer branding is also understood as a facet of corporate branding. Strategy development shifts employer branding engagement into contested territory: organizational agents versus organizational directions, experienced versus inexperienced strategists, new versus existing employees, HR versus marketing/branding, or middle versus top managers (Mölk, 2018). This strategy development struggles are recommended to be replaced by brand-related recruitment, which is based on facts

a) that portfolio advertising can be superior to mere corporate brand usage

b) brand portfolio strength and brand portfolio fit are important conditions for this effect and

c) the effect of brand portfolio strength is mediated by perceived person-organization fit and opportunities for professional development (Brunner and Baum, 2020).

Corporations are not alone presenting themselves as creators of harmonious society by delineation of negative participants. Mediation models by transfers of attitudes or building knowledge of customers (Lutz, MacKenzie and Belch, 1983; MacKenzie, Lutz and Belch, 1986; Mitchell and Olson, 1981; Shimp, 1981) delineate corporate implementation of socially controversial CSR initiatives (Turner, 2019) from the state policy. Former process-based approaches towards the three evolutionary stages: operational optimization, organizational transformation and system-building (Adams et al., 2016) explain why consumer behaviour was ignored from both marketing management, and CSR activities. However, bottom-up negative feedback of trials and errors of consumers has a clear developmental value, when creating awareness of deficiencies and motivating improvement (Andiola et al., 2018).

Discussions of positive and negative effects on trustworthiness have no negative effect on CSR perception (Jahn and Brühl, 2019) will be tested in our first hypothesis.

H1: Critique of CSR opposes social stabilising policy of states.

\section{Impact of CSR Ads With Behaviour of Individuals}

Between integration and disintegration of individuals and states with CSR, we see an opportunity to find a new CSR model respecting feedback inside and between the three groups of participants. Johnson et al. (2017) differentiates internal feedback according to varied outcomes of functional roles. Rogers (1983) splits feedback among groups of $2.5 \%$ innovators, $13.5 \%$ imitators, $34 \%$ early majority, 34\% late majority, and 16.5\% laggards. Bass (1969) has merged groups of innovators and imitators opposed to the remaining groups to predict the total turnover of innovation. We will merge both majority groups opposed to the groups in tails not according to the normal distribution, but according to the human life cycle. The human life cycle pushes people to protect kids, support for healing of criminals and addicts in its tails and encourages employees to support internal and outer unjust phenomena during the adult phase of the life cycle.

A CSR trustworthiness of strategy and brand of every company needs support of standardisation and development by engaged employees. An accepted critique creates a social responsibility, which may outperform technology and vice versa according to our second hypotheses.

H2: Social responsibility, which emerged from engagement in constructive critique, outperforms technology.

Firms are increasingly compensating their executives for CSR-related objectives instead of increased turnover from CSR. Ikram et al. (2019) justifies this preventive cost of CSR-contingent compensation by improvement of companies' social performance due to more volatile and unpredictable outcomes, which makes it hard to evaluate corporate executives' efforts. The volatile outcomes replaced possibly wrongly set objectives as compensation criteria by causal considerations about CSR recipe in specific contexts. Saridakis (2020) derived from 
divergent repertoires of CSR activities constellations of CSR engagement. The engagement of CSR volunteers was measured by scale with support of company's CSR, reduction of own volunteering, and CSR activities of companies at its anchors.

\section{Impact of Specific on General Attitudes}

General attitudes, which have the advantage of being relatively exogenous to the behaviour, only have a weak empirical association with specific travel behaviours (Kroesen and Chorus, 2018). The social identity theory suggests that employees' attraction, retention, commitment and motivation (Brammer et al., 2007; Peterson, 2004) are more likely selfidentified when organizations practice CSR. These general attitudes the social identity theory explains by motives from feedback experience (Adams et al., 2016; Jay and Gerand, 2015). But Dunning-Kruger (1999) denies experience by stating that people are not critical towards their own actions and values.

Therefore, this critique differentiates specific from general attitudes by conditions under which respondents have covered costs of own CSR volunteering, which was subject of more detailed hypotheses about preferences of specific type of messages (H1.1) on real behaviour, which have occurred one year later (H2.1).

H1.1.1: There is a relation between the preferred CSR activity of companies and respondents' own socially responsible behaviour in the selected areas.

H2.1.1: Respondents who behaved in a socially responsible way in the previous year, prefer CSR activities of companies.

\section{Methods Monitoring CSR Attitudes and Types of Messages}

Specific types of messages were collected according to types of CSR volunteering while general attitudes were collected form claimed CSR activities from companies. Change of both general attitudes and practiced specific volunteering was evaluated in comparison with year ago.

\section{Respondents and Data Collection}

The survey was processed by on-line questionnaires with a representative sample of $n=1038$ respondents from the population of the Czech Republic in the age range 18-65 years according to gender (530 men, 519 women), age (352 between 18 and 34 years; 467 between 35 and 64 years; 230 respondents older than 55 years), place of residency (178 respondents from villages up to 1000 inhabitants; 221 respondents from towns between 1001 and 5000 inhabitants; 179 respondents from towns between 5001 and 20000 inhabitants; 223 respondents from towns between 20001 and 100000 inhabitants; 248 respondents from towns bigger than 100001 inhabitants), education (483 fundamental school; 386 with maturity examination; 178 with university degree), and income. Income was rarely specified by respondents. The research results were analysed in the IBM SPSS software.

The average questionnaire filling-in took 30-35 minutes. The data were collected in November and December 2017 in an on-line panel of respondents of the IPSOS company in Prague in the Czech Republic. A quantitative exploratory research by two standardised questionnaires have compared the opinion of external observers by the question "Which areas should companies sponsor in order to be perceived as socially responsible?" with experience of volunteering "How socially responsibly do Czechs themselves behave?"

The questions were designed in a semi-open mode with more optional answers (multiple choice). The answers were recorded in binary nominal variables. The answers were rotated in each question in order to avoid the 'halo' effect. Option 'Other' has closed the list of answers to each question. If applied, the respondent was prompted to provide his very own answer.

Questions of first topic (Which areas should companies sponsor in order to be perceived as publicly responsible?):

Q1: According to your opinion, what should Czech companies sponsor in general?

- Education (broad accessibility to education, support of educational projects, etc.).

- Care, protection and support of projects aimed at senior citizens.

- Care, protection and support of projects aimed at disadvantaged citizens (socially or because of poor health, etc.).

- Humanitarian aid for victims of natural disasters or military conflicts or for population in developing countries in general.

- Support of community life (cultural, sport or charity activities) in place of your residency.

- Care, protection and support of projects aimed at children.

- Protection of environment and natural resources (utmost ecological production, recycling, etc.).

- Support of equality in the society (equal opportunities for women, ethnic minorities, the elderly).

- Support the resolution of public problems (crime rate, abuse of narcotics, etc.).

- Support of ethical entrepreneurship (behaviour towards suppliers, corruption prevention).

- Fair behaviour towards employees.

- Truthful communication towards customers.

- Support the development of modern technologies in order to enable them to support the society (health and safety, data protection, lean production, etc.).

- Other, please fill in. 
Questions of second topic How responsible do the Czechs themselves behave?

Q2: Did you behave yourself in a socially responsible way in the previous year?

- Contribution to a selected non-government organisation/single individual.

- Voluntary work for a selected non-government organisation/individual.

- Support, preparation of civic and community activities in the place of residency, participation in community politics.

- Consideration towards nature and environment.

- Other (please fill in).

- No.

Q3: What specifically was your contribution?

- Donation via SMS (DMS).

- I contributed in a public space collection.

- I contributed at a cultural event (beneficiary concert, market, etc.).

- I passed on items to a charity (cloth, toys, etc.).

- Donation via bank transfer or deposit on account of a specific non-government organisation.

- Other.

Q4: In what way did you behave more ecologically or in a more considerate way towards the environment?

- I separated the waste in my household.

- I made efforts to reduce the energy consumption (electricity or gas) and water.

- I used ecological appliances or bulbs.

- I reduced car travel and I preferred more ecological ways of travelling (public transport, bicycle).

- I preferred environment-friendly products (from ecological farms, recycled products or products not tested on animals).

- Other.

Q5: What would motivate you to participate in a socially responsible activity?

- Gender.

- Age.

- Region.

- Size of place of residency.

- Education.

- Amount of household members.

- Amount of economically active household members.

- Number of children in a household.

- Net monthly income of the household.

- Personal net monthly income of the respondent.

- Marital status.

\section{Data Processing Methods}

Respondent's own socially responsible behaviour was correlated with respondent's CSR claims, which companies should offer. Question "Are the preferences of the general public on socially responsible activities of companies in the Czech Republic related to their own socially responsible behaviour?" was used.

The relations between the variables were tested by the c2 method. Only pairs of variables at which a dependency was detected - Pearson c2 Asymptotic Significance (2-sided) $[p]=0.000-$ are mentioned. Moreover, adjusted residuals (Adjusted Residual |1.9|) were applied for the weighting of differences in cells of contingency tables.

Statistical data were analysed by an independence test of variables in contingency tables and by a twostep cluster analysis. Contingency tables were created, and an association analysis of nominal variables was applied. The association analysis explored the relation between answers of the first question (Which areas should companies sponsor in order to be perceived as socially responsible?) Q1 „According to your opinion, what should Czech companies sponsor in general?" from the first topic.

\section{RESULTS}

Daily performed or recalled activities from years ago were related to claimed CSR activities from corporations.

\section{CSR Preferences Customers Expect from Companies}

Answers to Q1 "According to your opinion, what should Czech companies sponsor in general?" rank what customers expect from CSR of companies.

Protection of environment and natural resources (utmost ecological production, recycling, etc.) have been chosen by $48.2 \%$ of the respondents. Fair behaviour towards employees have been chosen by $45.1 \%$ of the respondents. Almost a third (32.8\%) of the public prefers support activities in the education area (broad accessibility to education, support of educational projects, etc.) Even more than a quarter of the public (27.5\%) prefers truthful communication towards customers, and 25\% prefer activities supporting the development of modern technologies positively influencing the society (health and safety, data protection, lean production, etc.).

Other preferred socially responsible activities of companies attract one fifth of the public only. Support of ethical entrepreneurship (behaviour towards suppliers, corruption prevention) is preferred by $19.5 \%$ of the respondents. Care, protection and support of projects aimed at disadvantaged citizens (socially or due to poor health) are preferred by $16.8 \%$ of the public. Care, protection and support of projects aimed at children are preferred by $14.8 \%$. Even more than ten percent prefer care, protection and support of projects aimed at senior citizens (13.9\%).

Slightly less than ten percent $(9.8 \%)$, of the public prefer support of equality in the society (equal opportunities for women, ethnic minorities, 
the elderly). Almost the same share (9.3\%) prefer support of community life (cultural, sport or charity activities) in place of their residency. Supporting the resolution of current public problems (crime rate, abuse of narcotics...) is preferred by $8.8 \%$. Humanitarian aid for victims of natural disasters or military conflicts or for the population in developing countries in general is supported by $8.4 \%$.

How people themselves behave is asked by question Q2 "Did you behave in a socially responsible way in the previous year?". Social responsible behaviour accounts for $85 \%$ of the total. The most people state consideration towards nature and the environment 60\%. Fewer contributed to a selected non-government organization or an individual, 36\%. Further, with significant distance, the respondents mention voluntary work for a selected non-government organization or an individual, 18\% and less people support preparation of civic and community activities in the place of their residency, or they participate in community politics, $15 \%$.

Answers to question Q3 "In what way did you contribute specifically?” identify social responsible activities of people in the area of charity and donation. The biggest share of people passed on items to a charity (clothes, toys, etc.), 57\%. Further, $43 \%$ people contributed to a public space collection. $39 \%$ of people donate via bank transfer or a deposit to a specific non-government organization account). Almost one third (32\%) of people donate via SMS (DMS). 31\% contributed at a cultural event (beneficiary concert, market...).

Answers to question Q4 "In what way did you behave or had a more respectful attitude towards the environment?" are dominated by waste separation in households 94\%, usage of ecological appliances or bulbs $76 \%$, and efforts to reduce the energy consumption (electricity or gas) and water $71 \%$. Significantly less people (35\%) have announced reduced car traveling or more ecological ways of public transport, or bicycles. Lastly, 35\% of the respondents prefer environment-friendly products from ecological farms, recycled products or products not tested on animals.
The last open-ended question Q5. "What would motivate you to participate in a socially responsible activity?" more than a third (35\%) of respondents have answered that they don't know and 9\% of answers were missing. Answers, which are releasing or contributing to volunteering were sorted to following conditional types. If...

- I knew exactly where the finances ended, to whom they helped and to be sure to see the concrete results, 9\%.

- I myself had more money or a higher salary, 6\%.

- The project was really meaningful and interesting, $5 \%$.

- I could learn more about how to get involved, $5 \%$.

- I had more time (leisure time, employer support), $5 \%$.

- there was some profit for me (tax relief), 4\%.

- more people or companies were involved, $4 \%$.

Attitudes towards CSR type of specific and recalled messages

Differences between specific attitudes towards type of message are checked with those from a year ago.

Relatively few respondents claiming not to practice any CSR activities recalled support of kids $(N=21)$, criminals, addicts $(N=21)$ when suggesting CSR activities for companies. On the other end, respondents claiming to actively practice CSR activities recalled claims for equality $(\mathrm{N}=94)$ and environment $(\mathrm{N}=447)$ from companies. Statistics have balanced support of kids

a) in the introductory stage, and criminals and addicts

b) in ending phase CSR non-practicing respondents were assigned to the CSR of state. Support of equality

c) and environment protection

d) during the adult phase of life cycle of CSR practicing employees was assigned to CSR of corporations.

And, balance between both tails and body has offered opportunity to invite respondents, who have reacted on specific types of messages (Fig. 1).

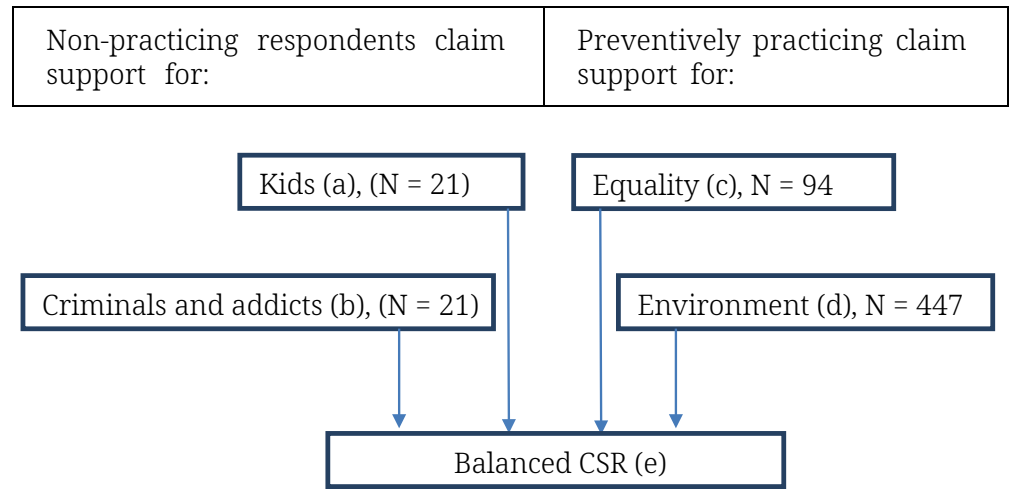

1: CSR requirements of practicing and non-practicing respondents 
H1 stating that more appealing CSR is due to the support of equality and environment protection in the adult phase of the life cycle than by support of kids, criminals and addicts in the tails of the life cycle was confirmed by to the number of respondents.

H2 stating that more appealing CSR effect is generated in the tails of the life cycle by kids, criminals and addicts in tails of life cycle than by support of equality and environment protection in adult phase of life cycle was confirmed by equal number of significant issues for activities performed year ago.

More detailed information from the statistical processing follows.

\section{Significance of the CSR Ends}

The analysis is based on the question Q2. "Did you behave in a socially responsible way in the previous year?” 85\% (880 people) of the respondents agreed they did one or more socially responsible activities such as nature \& ecology, donation to specific non-government organisations, various forms of volunteering, support of community activities, etc. On the other hand, 15\% respondents (158 people) stated that they did not behave in a socially responsible way in the previous year.

The survey question was "Is there any difference between both groups regarding their preferences on CSR activities of companies?"

There is a significant difference of respondents who behaved in a socially responsible way in their preference of protection of environment and natural resources. Respondents who behaved in a socially responsible way in previous year prefer significantly more CSR activities of companies targeting protection of environment and natural resources than those who didn't behave in a socially responsible way (adjusted residual 4.0).

Between the preference of CSR activities of companies targeting support of equal opportunities in the society and the behaviour of respondents there is a statistical dependence and significantly higher adjusted residual (2.2) in the cell responsible behaviour.
Between the preference of CSR activities of companies targeting care, protection and support of projects aimed at children and their own behaviour there is a statistical dependence and there is a significantly higher adjusted residual (2.6) in the cell responsible behaviour NO and care, protection and support of projects aimed at children YES.

Between the preference of CSR activity of companies targeting support of resolution of public problems (crime rate, abuse of narcotics, etc.) and the behaviour of respondents there is a statistical dependence and there is a significantly higher adjusted residual (2.2) in the cell responsible behaviour $N O$ and support of resolution of public problems (crime rate, abuse of narcotics, etc.) YES. H2.1.1 stating that respondents who behaved in a socially responsible way in the previous year prefer CSR activities of companies was not confirmed.

\section{Significance of Personal CSR Beginnings}

This analysis is related to the survey question „Are the preferences of the general public on socially responsible activities of companies in the Czech Republic related to their own socially responsible behaviour?" The Answers have been derived from the relation between questions Q2, Q3, Q4 ("How responsible do the Czechs themselves behave?") and question Q1 ("In your opinion, what should the Czech companies sponsor in general?") was explored by an association analysis.

The $\chi^{2}$ method was used to test relations between the variables. Symmetrical metrics of contingency coefficient was applied to the four-area tables with nominal variables. Adjusted residuals (Adjusted Residual $|1.9|$ ) has shown the weight of differences in the cells of contingency tables.

\section{Hypotheses}

HA1.1.0: There isn't any relation between the preferred CSR activity of companies and respondents' own socially responsible behaviour in selected areas.

\section{I: Former behaviour of respondents towards CSR}

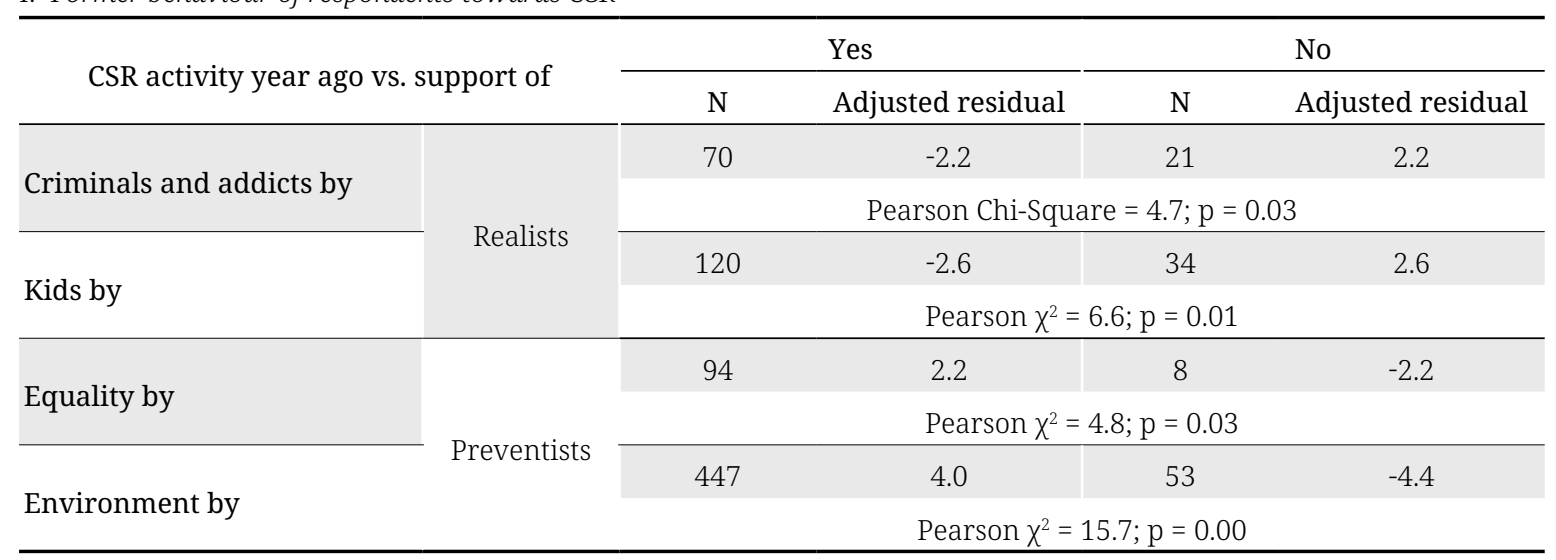


HA1.1.1: There is a relation between the preferred CSR activity of companies and respondents' own socially responsible behaviour in selected areas.

Hypothesis HA1.1.0 was rejected.

The answer to the survey question „The preferences of the general public on socially responsible activities of companies are related to their own socially responsible behaviour" was accepted for 22 pairs of depending variables out of 195. Possible variations were detected by applying the $\chi^{2}$ test even if the dependency was weak.

More specifically, there is a significantly higher rate of respondents who are considerate towards the nature and environment, and who prefer socially responsible activities of companies targeting protection of environment than of those who are not considerate towards nature and environment (adjusted residual 7.6).

There is a significantly higher rate of respondents who are considerate towards nature and environment, and who prefer socially responsible activities of companies targeting support of equality in the society than of those who do not prefer support of equality in the society (adjusted residual 2.1).

There is a significantly higher rate of respondents who are considerate towards nature and environment, and who prefer socially responsible activities of companies targeting support of ethical entrepreneurship than of those who do not prefer support of ethical entrepreneurship (adjusted residual 3.0).

There is a significantly higher rate of respondents who are considerate towards nature and environment, and who prefer socially responsible activities of companies targeting Truthful communication towards customers than of those who do not prefer truthful communication towards customers (adjusted residual 2.0).

There is a significantly higher rate of respondents who personally do not involve themselves in socially responsible activities and who prefer such activities of companies targeting care, protection and support of projects aimed at children than of those who do not prefer care, protection and support of projects aimed at children (adjusted residual 2.6).

There is a significantly higher rate of respondents who personally do not involve themselves in socially responsible activities and who prefer socially responsible activities of companies targeting support the resolution of public problems than of those who do not prefer support the resolution of public problems (adjusted residual 2.2).

There is a significantly higher rate of respondents who make donations via DMS, and who prefer socially responsible activities of companies targeting support of ethical entrepreneurship than of those who do not prefer support of ethical entrepreneurship (adjusted residual 2.1).
There is a significantly higher rate of respondents who contributed in a public space collection, and who prefer socially responsible activities of companies targeting fair behaviour towards employees than of those who do not prefer fair behaviour towards employees (adjusted residual 3.2).

There is a significantly higher rate of respondents who passed on items to a charity, and who prefer socially responsible activities of companies targeting protection of environment and natural resources than of those who do not prefer protection of environment and natural resources (adjusted residual 2.0).

There is a significantly higher rate of respondents who separated the waste in their households, and who prefer socially responsible activities of companies targeting protection of environment and natural resources than of those who do not prefer protection of environment and natural resources (adjusted residual 2.4).

There is a significantly higher rate of respondents who made efforts to reduce the energy and water consumption, and who prefer socially responsible activities of companies targeting protection of environment and natural resources than of those who do not prefer protection of environment and natural resources (adjusted residual 3.0).

There is a significantly higher rate of respondents who made efforts to reduce the energy and water consumption, and who prefer socially responsible activities of companies targeting support the development of modern technologies in order to enable them to enhance the society than of those who do not prefer support the development of modern technologies in order to enable them to support the society (adjusted residual 2.1).

There is a significantly higher rate of respondents who used ecological appliances or bulbs, and who prefer socially responsible activities of companies targeting support the development of modern technologies in order to enable them to enhance the society than of those who do not prefer support the development of modern technologies in order to enable them to enhance the society (adjusted residual 1.93).

There is a significantly higher rate of respondents who reduced car travel and preferred more ecological ways of travelling, and who prefer socially responsible activities of companies targeting support of ethical entrepreneurship than of those who do not prefer support of ethical entrepreneurship (adjusted residual 3.6).

There is a significantly higher rate of respondents who reduced car travel and preferred more ecological ways of travelling, and who prefer socially responsible activities of companies targeting support the development of modern technologies in order to enable them to enhance the society than of those who do not prefer support the development of modern technologies in order to enable them to enhance the society (adjusted residual 2.0). 
II: Claimed CSR priorities from companies

\begin{tabular}{|c|c|c|c|c|c|c|c|}
\hline & \multirow{2}{*}{$\mathrm{N}$} & \multirow{2}{*}{$\mathrm{p}$} & \multirow{2}{*}{$\begin{array}{l}\text { Adjusted } \\
\text { residual }\end{array}$} & \multicolumn{3}{|c|}{ Order of } & \multirow{2}{*}{ Sum } \\
\hline & & & & $\mathrm{N}$ & $\mathrm{p}$ & Total & \\
\hline \multicolumn{8}{|c|}{ Volunteers have claimed CSR support for } \\
\hline Environment protection & 500 & 0.000 & 7.6 & 1 & 1 & 1 & 2 \\
\hline Equal opportunities & 102 & 0.037 & 2.1 & 14 & $10-12$ & 14 & 25 \\
\hline Ethical entrepreneurship & 202 & 0.003 & 3.0 & 6 & $5-6$ & 5 & 11.5 \\
\hline Truthful customer communication about environment & 285 & 0.048 & 2.0 & 5 & $13-15$ & $8-9$ & 19 \\
\hline Donations for ethical entrepreneurship & 73 & 0.032 & 2.1 & 16 & $10-12$ & 15 & 27 \\
\hline Donations for equal treatment of employees & 168 & 0.001 & 3.2 & 8 & 4 & 6 & 12 \\
\hline Donations for environment & 200 & 0.045 & 2.0 & 7 & $13-15$ & $10-11$ & 21 \\
\hline Waste separators for environment & 360 & 0.018 & 2.4 & $2-3$ & 8 & 4 & 10.5 \\
\hline Energy saving environment & 360 & 0.003 & 3.0 & $2-3$ & $5-6$ & 3 & 8 \\
\hline Energy saving technologies & 161 & 0.039 & 2.1 & $9-11$ & $10-12$ & $10-11$ & 21 \\
\hline Investments to energy technologies & 161 & 0.050 & 1.9 & $9-11$ & 16 & 15 & 26 \\
\hline Ethical entrepreneurship reducing car traffic & 140 & 0.000 & 3.6 & 13 & 3 & 7 & 16 \\
\hline Car traffic reducing technologies & 161 & 0.046 & 2.0 & $9-11$ & $13-15$ & $12-13$ & 24 \\
\hline Prices of environment protecting products & 300 & 0.000 & 4.0 & 4 & 2 & 2 & 6 \\
\hline \multicolumn{8}{|c|}{ Non-volunteers have claimed CSR support for } \\
\hline Kids & 154 & 0.010 & 2.6 & 12 & 7 & $8-9$ & 19 \\
\hline Crime, or addiction & 91 & 0.029 & 2.2 & 15 & 9 & $12-13$ & 24 \\
\hline
\end{tabular}

Surprisingly, support for seniors is not claimed significantly. Therefore, it is not part of 15 CSR priorities in Tab. II.

There is a significantly higher number of respondents who preferred environment-friendly products, and who prefer socially responsible activities of companies targeting protection of environment and natural resources than of those who do not prefer protection of environment and natural resources (adjusted residual 4.0).

\section{DISCUSSION}

Efficiency of advertising is based on one of the four combinations as follows:

Firstly, only mainstream environment $(\mathrm{N}=447)$ when other CSR priorities fell of.

Secondly, general attitude towards environment adapts to equals with or without specific call for equal support of kids, seniors and criminals by CSR non-volunteers $(\mathrm{N}=21)$ and support of equality $(\mathrm{N}=94)$ of minorities in regular working environment. Equality-based specific attitudes trigger behaviour to prevent decline of status of individuals. Therefore, CSR of corporations should consider whether specific attitudes towards equality during specific P. R. events will complement each other, support general preventive attitude towards environment or general progressive attitude towards technology $(\mathrm{N}=161)$. This innerouter and preventive-progressive dynamics was not found in symmetry control of several $(H \infty)$ mathematical optimization trials (Liu et al., 2019). Also, interpurchase-timing by duration analysis repeatedly controlling mathematical optimization trials of real and imaginary appeals (Igari and Hoshino, 2018) is focusing on trends only. Precision of our variables was expressed by adjusted residual of cluster analysis according to hidden (imaginary) and performed social activities on requested priorities from the corporate strategies (CSR) in contingency tables. This feedback tracking markers make our method operable in different context.

\section{CONCLUSION}

The objective of this article was to find indices, which homogenize CSR campaigns of corporations according to specific attitudes and behaviour of individuals. Reduction to four items (environment and equality of CSR practicing and kids, criminals and addicts of rejecting CSR practicing) from a year ago (Tab. I) opposed to a long list of specific CSR activities (Tab. II) is more precise than performed cluster analysis. 
Firstly, CSR volunteering non-practicing respondents call for support for kids, criminals and addicts. It demonstrates their responsibility not only to people in need. It may be call to simplify the complex public, corporations and human relationships and focus them on its development. The free capacity of non-practitioners of volunteering allows them to release their responsibility in periods of scandals and extreme situations of price war or pandemic. Practicing CSR volunteering takes off the capacity of help in urgent situations. Therefore, the balance of CSR non-practitioners and practitioners should be further investigated.

Secondly, the altered impact of technology and CSR non-practitioners on emerging responsibility of supported criminals and addicts should be explained by theoreticians. Oppose roles complementing responsibilities of CSR practitioners and non-practitioners towards the company and the state exceed the framework of the recent CSR concepts and optimisation models (Liu et al., 2019). These complementary opposed roles are hidden or under-used by both practice and science. Only positive friendly helpers are promoted while critics are often overlooked if not rejected. Therefore, neither organizations nor states have constructive supporters in crisis. This CSR policy from top down seems to be irresponsible

Confirmatory test of variability of verbal formulations of different actors and evaluation of CSR performance in crisis is limitation of this article is passed to next research. Authors intend to add data for year 2020 to contribute to the lacking data from the crisis.

\section{REFERENCES}

ADAMS, R., JEANRENAUD, S., BESSANT, J., DENYER, D. and OVERY, P. 2016. Sustainability-oriented innovation: a systematic review. Int. J. Manag. Rev., 18(2): 180-205.

ANDIOLA, L. M. and BEDARD, J. C. 2018. Delivering the "tough message": Moderators of subordinate auditors' reactions to feedback. Accounting, Organizations and Society, 70: 52-68.

BASS, F. 1969. A new product growth model for consumer durables. Management Science, 15(5): 215-227.

BLOOM, T. 2015. The Business of Migration Control: Delegating Migration Control Functions to Private Actors. Global policy, 6(2): 151-157.

BRAMMER, S. J. and PAVELIN, S. 2006. Corporate reputation and social performance: The importance of fit. Journal of Management Studies, 43(3): 435-455.

BRUNNER, C. B. and BAUM, M. 2020. The impact of brand portfolios on organizational attractiveness. Journal of Business Research, 106: 182-195.

HERSHER, R. 2017. Starbucks says it will hire 10,000 refugees worldwide in the next 5 years. National Public Radio. [Online]. Available at: http://www.npr.org/sections/thetwo-way/2017/01/30/512427887/ starbucks-says-it-will-hire-10-000-refugees-worldwide-in-next-5-years [Accessed: 2017, September 1].

IGARI, R. and HOSHINO, T. A. 2018. Bayesian data combination approach for repeated durations under unobserved missing indicators: Application to interpurchase-timing in marketing. Computational Statistics \& Data Analysis, 126: 150-166.

IKRAM, A., LI, Z. F. and MINOR, D. 2019. CSR-contingent executive compensation contracts. Journal of Banking \& Finance, in press.

JAHN, J. and BRÜHL, R. 2019. Can bad news be good? On the positive and negative effects of including moderately negative information in CSR disclosures. Journal of Business Research, 97: 117-128.

JAY, J. and GERAND, M. 2015. Accelerating the Theory and Practice of Sustainability-oriented Innovation. MIT Sloan School Working paper. Cambridge, MA: MIT.

JOHNSON, J. S., MATTHES, J. M. and FRIEND, S. B. 2019. Interfacing and customer-facing: Sales and marketing selling centers. Industrial Marketing Management, 77: 41-56.

KROESEN, M. and CHOROUS, C. 2018. The role of general and specific attitudes in predicting travel behavior - A fatal dilemma? Travel Behaviour and Society, 10: 33-41.

KRUGER, J. and DUNNING, D. 1999. Unskilled and Unaware of It: How Difficulties in Recognizing One's Own Incompetence Lead to Inflated Self-Assessments. Journal of Personality and Social Psychology, 77(6): 1121-1134.

LIU, M., LAM, J., ZHU, B. and KWOK, K-W. 2019. On positive realness, negative imaginariness, and Hळ control of state-space symmetric systems. Automatica, 101: 190-196.

LUTZ, R. J., MACKENZIE, S. B. and BELCH, G. E. 1983. Attitude toward the ad as a mediator of advertising effectiveness: Determinants and consequences. Advances in Consumer Research, 10: 532-539.

MACKENZIE, S. B., LUTZ. R. J. and BELCH, G. E. 1986. The role of attitude toward the ad as a mediator of advertising effectiveness: A test of competing explanations. Journal of Marketing Research, 23(2): 130-143. 
MITCHELL, A. A. and OLSON, J. C. 1981. Are product attribute beliefs the only mediator of advertising effects on brand attitudes? Journal of Marketing Research, 18: 318-322.

MÖLK, A. 2018. Structures, strategizing, and contested territories: A structuration perspective on strategy development in employer branding. Scandinavian Journal of Management, 34(4): 326-334.

OEIJ, P. R. A., VAN DER TORRE, W., VAAS, F. and DHONDT, S. 2019. Understanding social innovation as an innovation process: Applying the innovation journey model. Journal of Business Research, 101(8): 243-254.

PETERSON, D. K. 2004. The relationship between perceptions of corporate citizenship and organizational commitment. Business and Society, 43(3): 296-319.

RAWSON, A., DUNCAN, E. and JONES, C. 2013. The Truth about Customer Experience. Harvard Business Review, 91: 1-10.

ROGERS, E. M. 1983. Diffusion of Innovations. London: The Free Press.

ROSLING, H., ROSLING, O. and ROSLING RÖNNLUND, A. 2018. Factfulness: Ten Reasons We're Wrong About the World - and Why Things Are Better Than You Think. Sceptre.

SARIDAKIS, C., ANGELIDOU, S. and WOODSIDE, A. G. 2020. What type of CSR engagement suits my firm best? Evidence from an abductively-derived typology. Journal of Business Research, 108: 174-187.

SHIMP, T. A. 1981. Attitude toward the ad as a mediator of consumer brand choice. Journal of Advertising, 10(2): 9-15.

TUNER, M. R., MCINTOSH, T., REID, S. W. and BUCKLEY, M. R. 2019. Corporate implementation of socially controversial CSR initiatives: Implications for human resource management. Human Resource Management Review, 29(1): 125-136.

Contact information

Zdeněk Linhart: linhart.zdenek@gmail.com 